\title{
Leucine-Rich Repeat-Containing G-Protein Coupled Receptor 6
}

National Cancer Institute

\section{Source}

National Cancer Institute. Leucine-Rich Repeat-Containing G-Protein Coupled Receptor 6. NCI Thesaurus. Code C118965.

Leucine-rich repeat-containing G-protein coupled receptor 6 (967 aa, 104 kDa) is encoded by the human LGR6 gene. This protein is involved in both binding to R-spondin proteins and potentiating ligand-dependent signaling pathways. 